\title{
Effects of Feeding and Copulation on Ultrastructural Changes of the Tubular Glands of Genés Organ in Female Haemaphysalis longicornis (Acari: Ixodidae)
}

\author{
Hiroyuki KAKUDA, Takayuki MŌRI and Satoshi SHIRAISHI \\ Zoological Laboratory, Faculty of Agriculture, Kyushu University \\ 46-06, Fukuoka 812-81, Japan.
}

(Received 26 September 1994; Accepted 6 March 1995)

\begin{abstract}
Kakuda, H., T. Mōri and S. Shiraishi, 1995. Effects of feeding and copulation on ultrastructural changes of the tubular glands of Genés organ in female Haemaphysalis longicornis (Acari: Ixodidae). J. Acarol. Soc. Jpn., 4(1): 1-13.

Gené's organ which everts from the camerostome and coats the egg surface with waterproofing wax is indispensable for egg hatching. The ultrastructure of the tubular glands of Genés organ in Haemaphysalis longicornis changes dramatically in accordance with stimuli of feeding and copulation. Cell proliferation followed by membrane supply due to fusing of small vesicles with the apical plasma membrane is induced by the onset of feeding. After the copulation, deep intercellular crypts with well-developed microvilli are formed and cell surface is conspicuously enlarged. The experiment using fed virgin females confirmed that these crypts cannot be formed without copulation. Simultaneously with crypt formation, abundant cytoplasmic inclusions are accumulated. In spite of secretion of abundant wax from the tubular glands, no exocy tosis occurs during oviposition. This fact suggests that the low molecular compounds are released from the glandular cells by transmembrane transport.
\end{abstract}

Key words: egg wax, Gené's organ, Haemaphysalis longicornis, tubular gland, ultrastructural change

\section{INTRODUCTION}

Tick's Gené's organ observed in adult females is specialized for oviposition (Lees and Beament, 1948; Arthur, 1953). In ixodids, this organ is composed of the horns everted from the camerostome between the posterior edge of the basis capituli and the anterior margin of the scutum, and the tubular glands in the haemocoel. During oviposition the emerged horns grasp an egg deposited from the genital aperture, when the egg is coated with wax. This surface egg wax from the tubular glands of Genés organ prevents excessive water loss and the growth of fungi (Lees and Beament, 1948). Thus, eggs deposited without contact of Gené's organ cannot hatch (Kakuda et al., 1992). The ultrastructure of the tubular glands in ixodids has been investigated (Booth et al., 1984 for Boophilus microplus; El Shoura, 1987 for Hyalomma dromedarii; Booth, 1989 for $B$. 
microplus and Rhipicephalus appendiculatus), however, influence of copulation stimuli which apparently control the female feeding on the ultrastructural changes of the tubular glands has not been described. Well-developed microvilli on the free surface, elaborated array of rough endoplasmic reticulum and Golgi complexes in the glandular cell of above ticks indicate that the tubular glands are typical wax gland.

Ixodid females have a single gonotrophic cycle, namely, an adult female feeds a single host once, and after the engorgement and detachment from the host, she lays eggs and dies. Rapid ingestion and engorgement followed by detachment are not occur without copulation; copulation triggers the dramatic changes in physiology and morphology of feeding females. Therefore, the present study is designed to clarify the effects of feeding and copulation on ultrastructural changes of the glandular cells which constitute the tubular glands of Gene's organ in Haemaphysalis longicornis and to discuss the characteristics and functions of the cells.

\section{MATERIALS AND METHODS}

Adult Haemaphysalis longicornis (bisexual strain) collected by dragging on pastures in Kuju Highland, Oita Prefecture were fed on the ears of laboratory rabbits. Engorged females were maintained in a dark incubator at constant temperature and humidity $\left(30^{\circ} \mathrm{C}, 90 \% \mathrm{RH}\right)$.

Unfed, feeding ( 5 days after attachment), engorged ( 1 and 3 days after copulation) and ovipositing (1 day after the onset of oviposition) females were used. Also 10-day

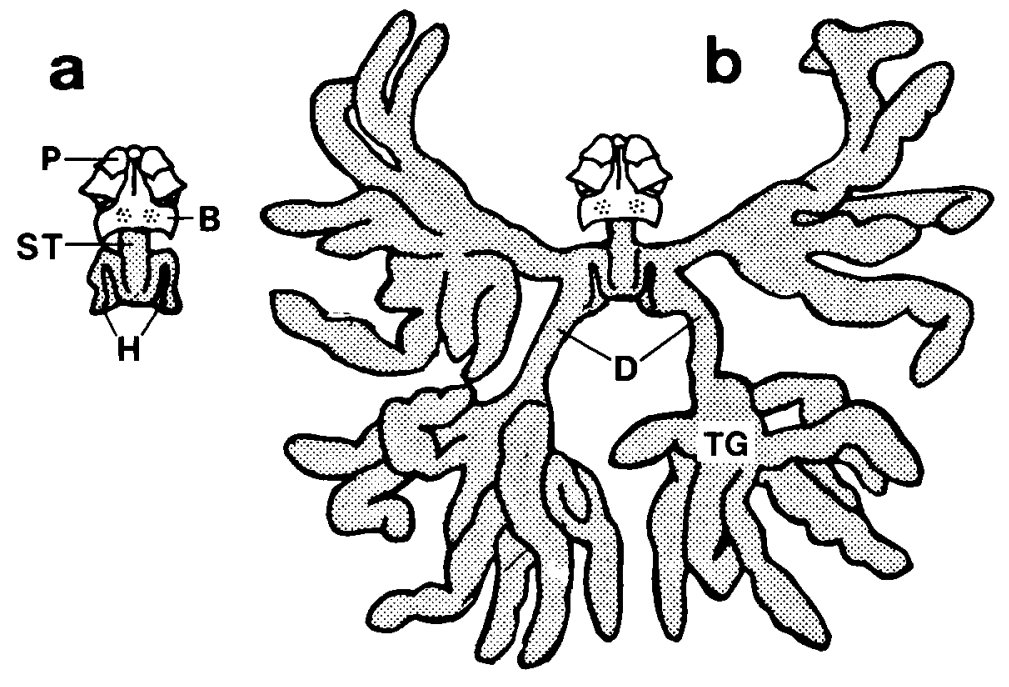

Fig. 1. Diagrams showing Gene's organ in the unfed and the ovipositing female. a: The unfed Genés organ consists of the short stalk (ST) and bilobed horn (H). Undeveloped tubular gland is invisible. b: Gené's organ of the ovipositing female has four bunches of large digitate tubular glands (TG) which are connected with the horn by ducts (D). B: basis capituli, P: palp. 
feeding virgin females were used to examine the effects of copulation on development of the tubular glands of Gené's organ. The removed Genés organ was fixed with $3 \%$ glutaraldehyde in $0.1 \mathrm{M}$ sodium cacodylate buffer $\left(4^{\circ} \mathrm{C}, \mathrm{pH} 7.2\right)$, washed thoroughly in the same buffer, and then post-fixed with $1 \% \mathrm{OsO}_{4}$ in the same buffer. The tissues were dehydrated in a graded ethanol series and propylene oxide, and embedded in epoxy resin. Thin sections $(\sim 60 \mathrm{~nm})$ were cut on a Porter-Blum MT-1 microtome, using a glass knife, and doubly stained with uranyl and lead acetate before examination in an Hitachi H-600 A electron microscope. Semithin sections $(\sim 1.5 \mu \mathrm{m})$ for light microscopy were stained with toluidine blue.

\section{RESULTS}

Gené's organ of Haemaphysalis longicornis, which is situated immediately beneath the anterior region of the scutum, is composed of a short stalk and a pair of horns in the unfed stage (Fig. 1 a). The glandular epithelium distributed in the peripheral region of the horns conspicuously develops during feeding and becomes four bunches of large

a
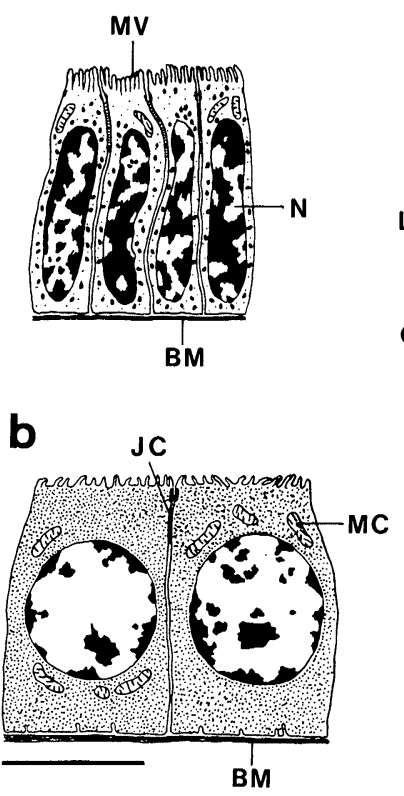

C

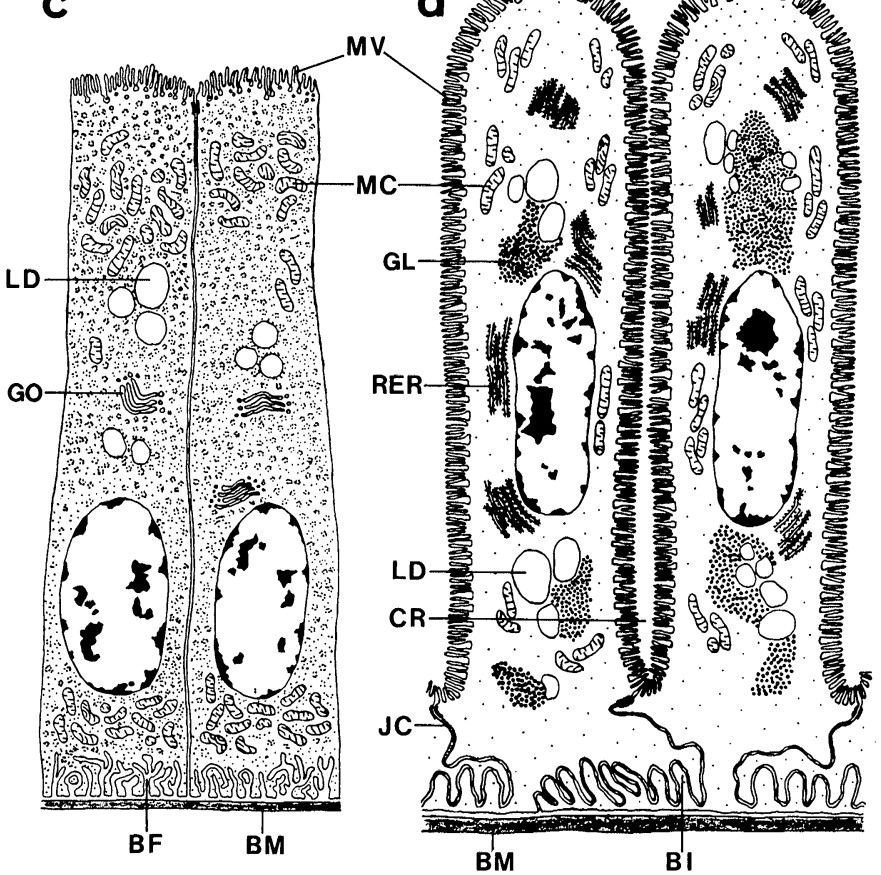

Fig. 2. Diagrams showing ultrastructural changes of the glandular epithelial cell of Gené's organ. a: Unfed female. b: Feeding female (5-day after attachment). c: Detached female (1-day after copulation). d: Ovipositing female. BF: basal fold, BI: basal interdigitation, BM: basement membrane, CR: intercellular crypt, GL: glycogen particles, GO: Golgi complex, JC: junctional complex, LD: lipid droplet, MC: mitochondrion, MV: microvilli, N: nucleus, RER: rough endoplasmic reticulum. (Bar $=10 \mu \mathrm{m}$ ) 




Fig. 3. Electron micrograph showing the glandular epithelium of Genés organ in the unfed female. a: The peripheral region of the horn of Genés organ. The horn epithelium (EP) consisting of the cuboidal cells is covered with the inner cuticle (IC). (Bar $=10 \mu \mathrm{m}$ ) b: The glandular epithelium consisting of the columnar cells. The cell cytoplasm is occupied by irregularly shaped nucleus with abundant heterochromatin. $(\mathrm{Bar}=2 \mu \mathrm{m}) \mathrm{c}$ : Apical surface of the glandular epithelial cells. Scanty microvilli (MV) are present on the cell apices. (Bar $=1 \mu \mathrm{m})$ BM: basement membrane, DG: electron-dense granular structure, GE: glandular epithelium, L: lumen, N: nucleus, SJ: septate junction. 
simple branched tubular glands connected with the stalk by two pairs of ducts (Fig. 1 b; cf. Kakuda et al., 1992). The results of this great morphological changes (Fig. 2) in the tubular glands during and after feeding, and those of fed virgin females are given below.

\section{Unfed females}

Columnar glandular epithelium locates in the peripheral region of the horns, and the remainder near the stalk is cubical epithelium of which apical surface is covered with the inner cuticle (Fig. 3 a). The undeveloped glandular epithelial cells with poor organelles are occupied by the irregularly shaped nucleus with dense heterochromatic clumps (Figs. 2 a, 3 b). Adjacent cells which have undeveloped microvilli on the apical surface are joined by the septate junction (Fig. $3 \mathrm{c}$ ).

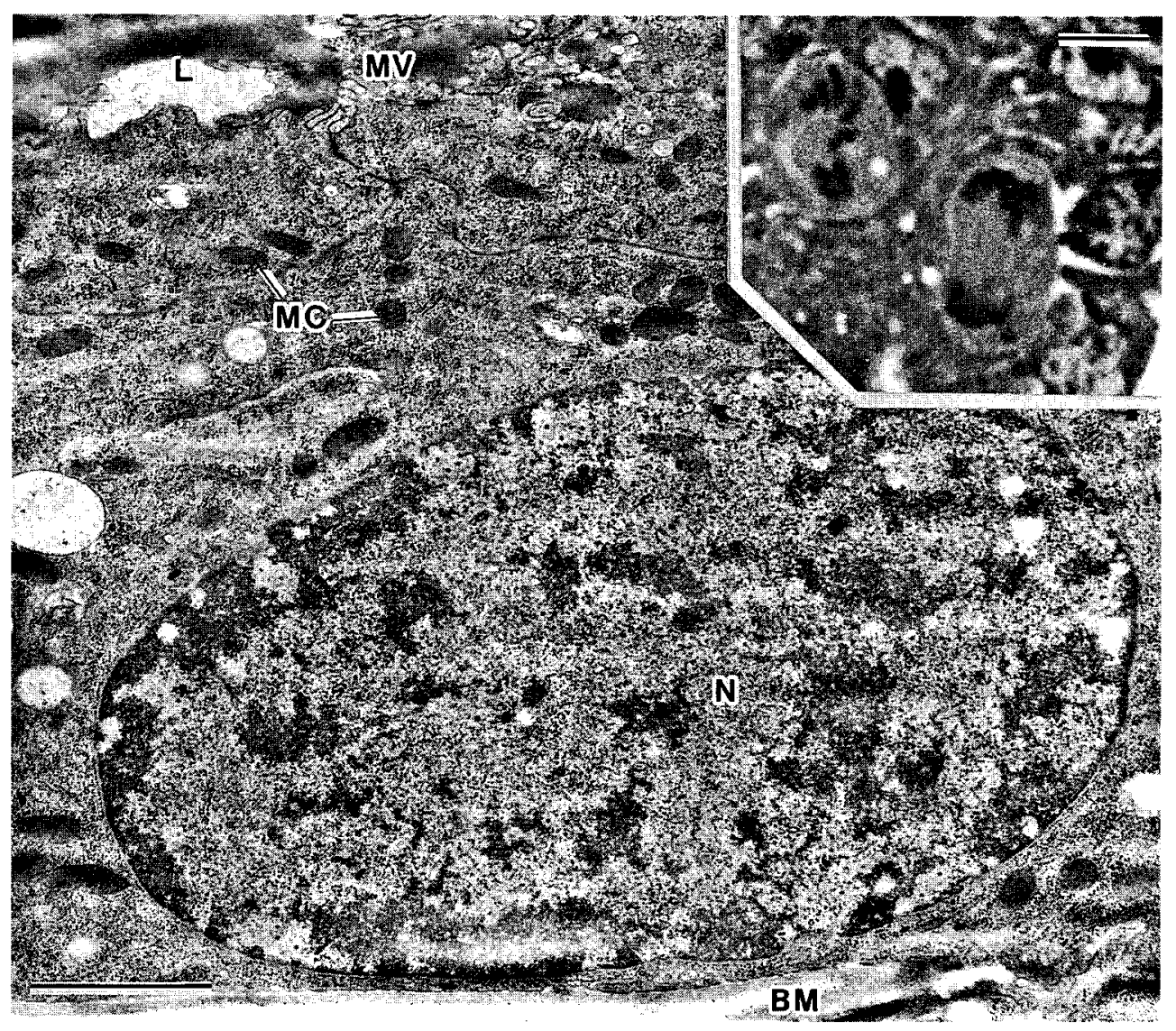

Fig. 4. Electron micrograph of the tubular gland of Genés organ in 5-day feeding female. The cuboidal glandular epithelial cell contains a large round nucleus and abundant free ribosomes. (Bar $=2 \mu \mathrm{m}$ ) Inset: Light micrograph indicates anaphase of mitosis in the cells. $(B a r=10 \mu \mathrm{m})$ BM: basement membrane, L: lumen, MC: mitochondrion, MV: microvilli, N: nucleus. 


\section{Feeding females}

Although the height of the glandular epithelial cells on the 5 th day in feeding are comparable to that of the unfed females, the cells become cuboidal by increase in width (Figs. $2 \mathrm{~b}, 4$ ). The cells have poorly developed microvilli and contain round nucleus with decreased heterochromatin and numerous free ribosomes. Some stages of mitosis occur in this feeding stage (Fig. 4 inset).

\section{Engorged females}

In $H$. longicornis, copulated females on the host engorge rapidly and detach from the host 1-2 days after the copulation. In the engorged females on the 1st day after copulation, the glandular epithelial cells increase in volume and become $40-45 \mu \mathrm{m}$ in height (Fig. $2 \mathrm{c}$ ). The junctional complex consisting of the zonula adherens and septate junction combines adjacent cells in the apical region (Fig. 5 a inset), and small vesicles are actively fusing with the apical plasma membrane which projects well-developed microvilli (Fig. 5 a). In the cytoplasm, numerous polysomes (Fig. $5 \mathrm{a}$, b and left inset of b), Golgi complexes (Fig. 5 b right inset), lipid droplets and many mitochondria are observed, and large round nucleus with increased euchromatin is situated in the basal region. The basal plasma membrane has infoldings and the basement membrane becomes thick (Fig. 5 b).

On the 3rd day after copulation (the 2nd day after detachment), the deep intercellular crypts are formed by a falling of the microvillar border into the basal region, thus the junctional complex located in the apical region until the 1st day after copulation is moved near to the basement membrane (Fig. 6 a). Microvilli (diam. $\sim 0.09 \mu \mathrm{m}$, length $\sim$ $0.8 \mu \mathrm{m}$ ) on the free surface exhibit the brush border (Fig. $6 \mathrm{~b}$ ). The cytoplasm contains numerous polysomes, rough endoplasmic reticulum, and mitochondria (Fig. $6 \mathrm{a}$ ). In addition, the cytoplasmic inclusions (lipid droplets and glycogen particles) increase (Fig. $6 \mathrm{a}, \mathrm{c}$ ).

\section{Ovipositing females}

The glandular epithelial cells with domed apical region separated by the deep intercellular crypts become $60-80 \mu \mathrm{m}$ in height and have large oval nucleus in the midregion of the cytoplasm (Figs. $2 \mathrm{~d}, 7$ ). Each microvillus becomes more slender (diam. $0.12 \mu \mathrm{m}$, length $\sim 1.2 \mu \mathrm{m}$ ) than that found on the 3rd day after copulation, and branches into 2-3 pieces (Fig. 8a). The lateral plasma membrane of adjacent cells forced down with the junctional complex (Fig. 8 b) by development of the deep crypt exhibits numerous interdigitations in the basal region (Fig. $8 \mathrm{c}$ ). The cytoplasm contains numerous mitochondria and glycogen particles, lipid droplets and rough endoplasmic reticulum (Figs. 7,8 a). The lumen is filled with a little dense materials.

\section{Fed virgin females}

$H$. longicornis females of the bisexual strain cannot engorge and remain attaching to the host without copulation. In 10-day feeding virgin females, the glandular epithelial cells become $20-25 \mu \mathrm{m}$ in height, but the height is nearly half of that on the 1st day after 

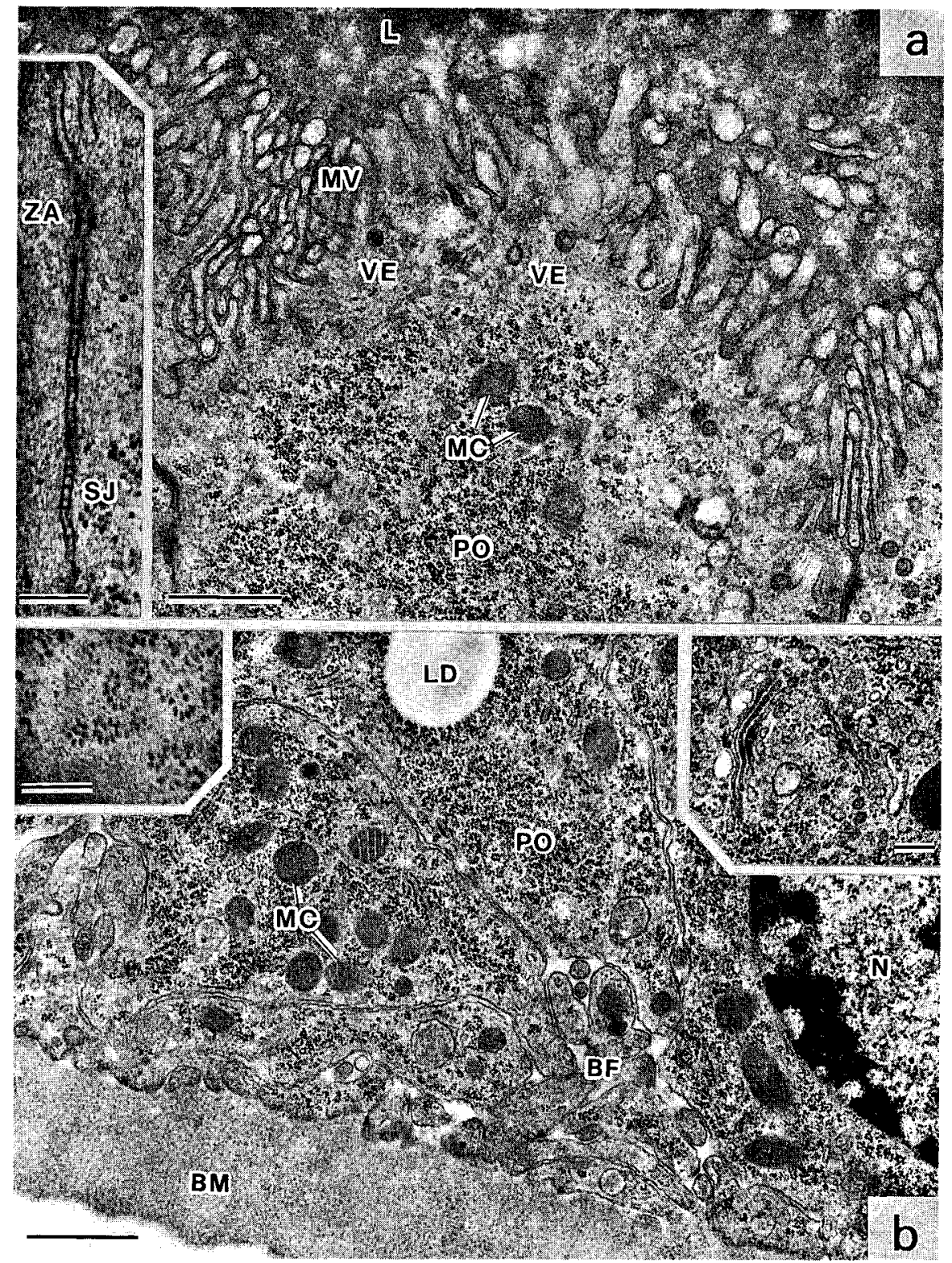

Fig. 5. Electron micrograph of the tubular gland of Gene's organ in the engorged female (1-day after copulation). a: The apical portion of the glandular epithelial cell. The small vesicles (VE) fuse with the apical plasma membrane, forming exocytic vesicle. Inset: The adjacent cells cohere together by the zonula adherens (ZA) and septate junction (SJ) in the apical region. b: The basal region of the cell. The basal plasma membrane has many infolds (BF) closely associated with mitochondria (MC). The cytoplasm contains a large quantity of polysomes (left inset) and Golgi complex (right inset). BM: basement membrane, L: lumen, LD: lipid droplet, MV: microvilli, N: nucleus. (Bar $=1 \mu \mathrm{m}$, inset $\operatorname{bar}=0.2 \mu \mathrm{m}$ ) 


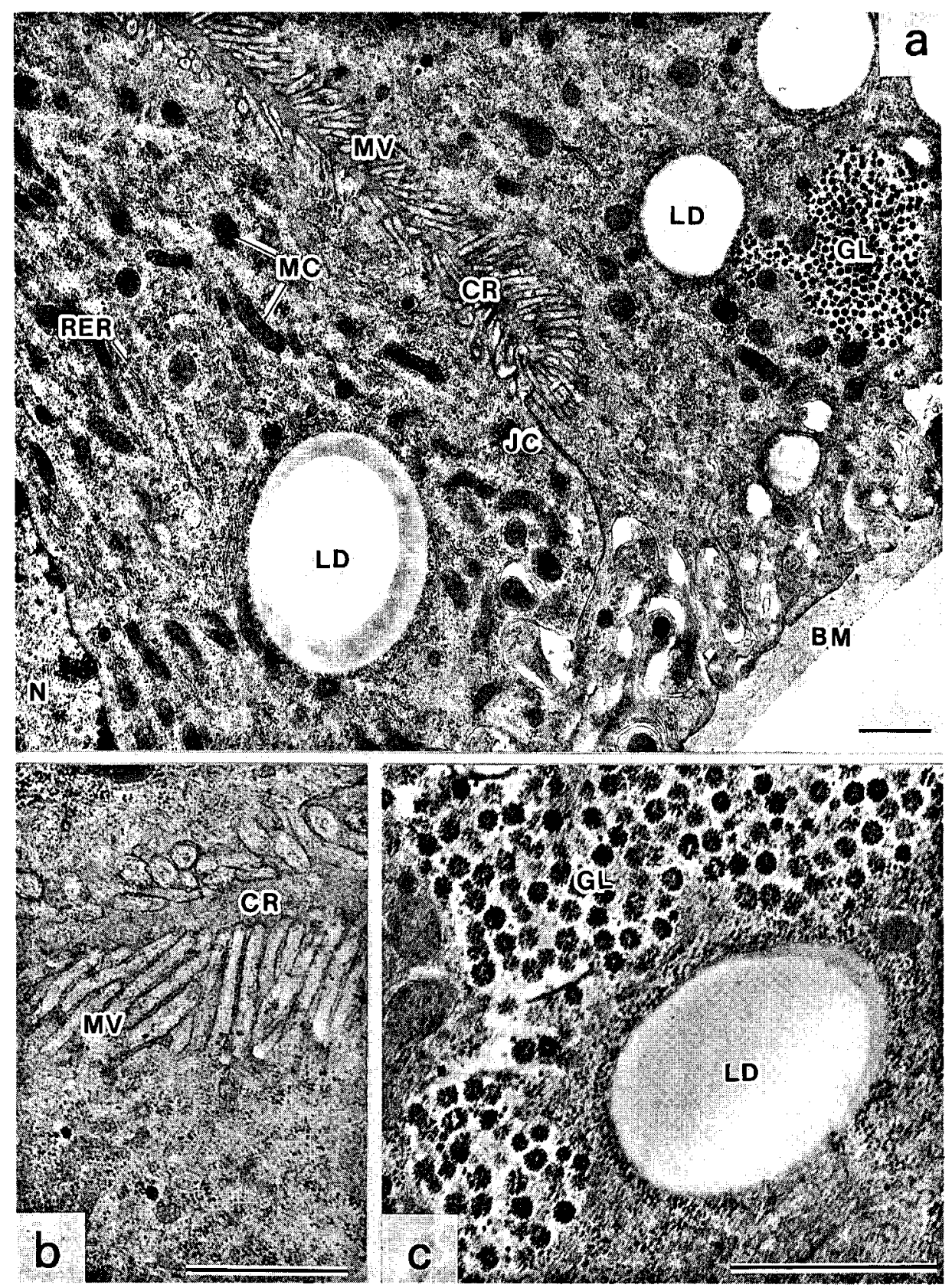

Fig. 6. Electron micrograph of the tubular gland of Genés organ in the engorged female (3-day after copulation). a: The junctional complex (JC) is forced down close to the basement membrane by development of the deep intercellular crypt (CR). b: Microvilli (MV) around the intercellular crypt (CR). c: Abundant glyeogen particles (GL) and lipid droplets (LD) in the cytoplasm. BM: basement membrane, MC: mitochondrion, N: nucleus, RER: rough endoplasmic reticulum. $(\mathrm{Bar}=1 \mu \mathrm{m})$ 




Fig. 7. Electron micrograph of the tubular gland during oviposition, showing the welldeveloped glandular epithelial cells with deep intercellular crypts (CR). The lumen (L) is distended with secretions. BM: basement membrane, GL: glycogen particles, LD: lipid droplet, MC: mitochondrion, MV: microvilli, $\mathrm{N}$ : nucleus, RER: rough endoplasmic reticulum. $(\mathrm{Bar}=5 \mu \mathrm{m})$ 
copulation (cf. Fig. 2c). The apical plasma membrane projects well-developed microvilli and numerous mitochondria and polysomes are found in the cytoplasm, however, adjacent cells are joined by the junctional complex in the apical region, therefore no intercellular crypts are formed (Fig. 9 a). Numerous small vesicles are fusing with the plasma membrane in the apical intercellular region and microvilli are packed with this portion (Fig. 9 b).

\section{DISCUSSION}

Gené's organ of Haemaphysalis longicornis is basically similar to that of the other Ixodidae (Arthur, 1953 for Ixodes hexagonus; Balashov, 1972 for Hyalomma asiaticum; Booth et al., 1984 for Boophilus microplus; El Shoura, 1987 for Hyalomma dromedarii).

Ultrastructure of the tubular glands of $H$. longicornis changes dramatically in accordance with some events which adult females undergo. The onset of feeding causes the enlargement of the glandular epithelial cells and the increase in free ribosomes followed by cell proliferation. Since the fusion of the membrane of secretory vesicles with the plasma membrane increases in an area of the cell surface (Palade, 1975), the active fusion of small vesicles with the apical plasma membrane found on the 1st day after copulation before occurrence of the secretory activity of the gland may contribute to membrane supply into the plasma membrane for formation of great numerous microvilli on the free surface including the region of the intercellular crypts in the future.

Intercellular crypts formed after copulation enable the microvillar free surface to increase, also which may contribute to great expansion of the cell surface. This great increase in the surface area of the plasma membrane suggests that secretions from the tubular glands are released by transmembrane transport. Results of the experiments using long-term feeding virgin females reveal that polysome formation and exocytosis-like phenomenon occur during feeding without copulation, but it is indispensable for formation of the intercellular crypts to copulate. The period from the onset to completion of crypt formation synchronizes with the preoviposition period.

General characteristics of transporting epithelia, i.e. well-developed microvilli on the free surface and basal infoldings of the plasma membrane (Berridge and Oschman, 1972), are observed in the tubular glands of Gené's organ on the 1st day after copulation, and 2 days after, numerous glycogen particles and lipid droplets are accumulated in the cytoplasm. However, no basal infoldings in the ovipositing females suggests that intake of precursors of secretions from the haemolymph has already completed before the onset of oviposition. Thus, the glandular epithelial cells change their function during and after feeding; formation of the intercellular crypts, intake of precursors and their accumulation are occurred for a few days from copulation to the onset of oviposition, and secretion is during oviposition.

Secretions from developed glandular epithelial cells released by transmembrane transport probably originate from glycogen particles and lipid droplets in the cytoplasm, suggests that they are low molecular compounds. The egg wax is composed of complicated constituents such as branched and non-branched chain alkanes, steroids, 


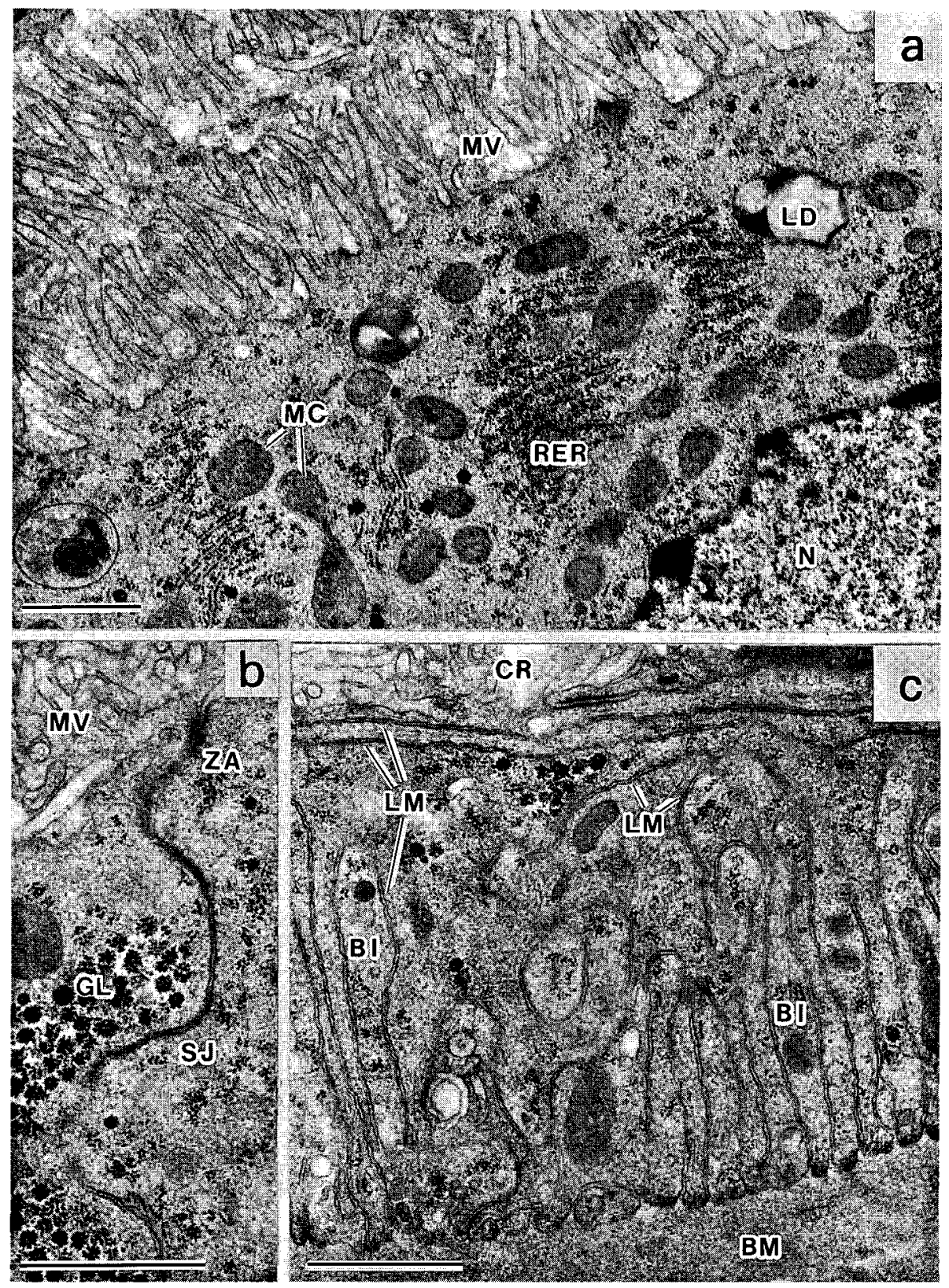

Fig. 8. Electron micrograph of the tubular gland of Genés organ as in Fig. 7. a: The lumenal surface projects well-developed microvilli (MV). b: The junctional complex close to the basement membrane, showing the zonula adherens ( $Z A)$ and septate junction (SJ). c: The basal region showing interdigitations of the lateral plasma membrane (LM). BI: basal interdigitation, BM: basement membrane, CR: intercellular crypt, GL: glycogen particles, LD: lipid droplet, MC: mitochondrion, N: nucleus, RER: rough endoplasmic reticulum. (Bar $=1 \mu \mathrm{m}$ ) 

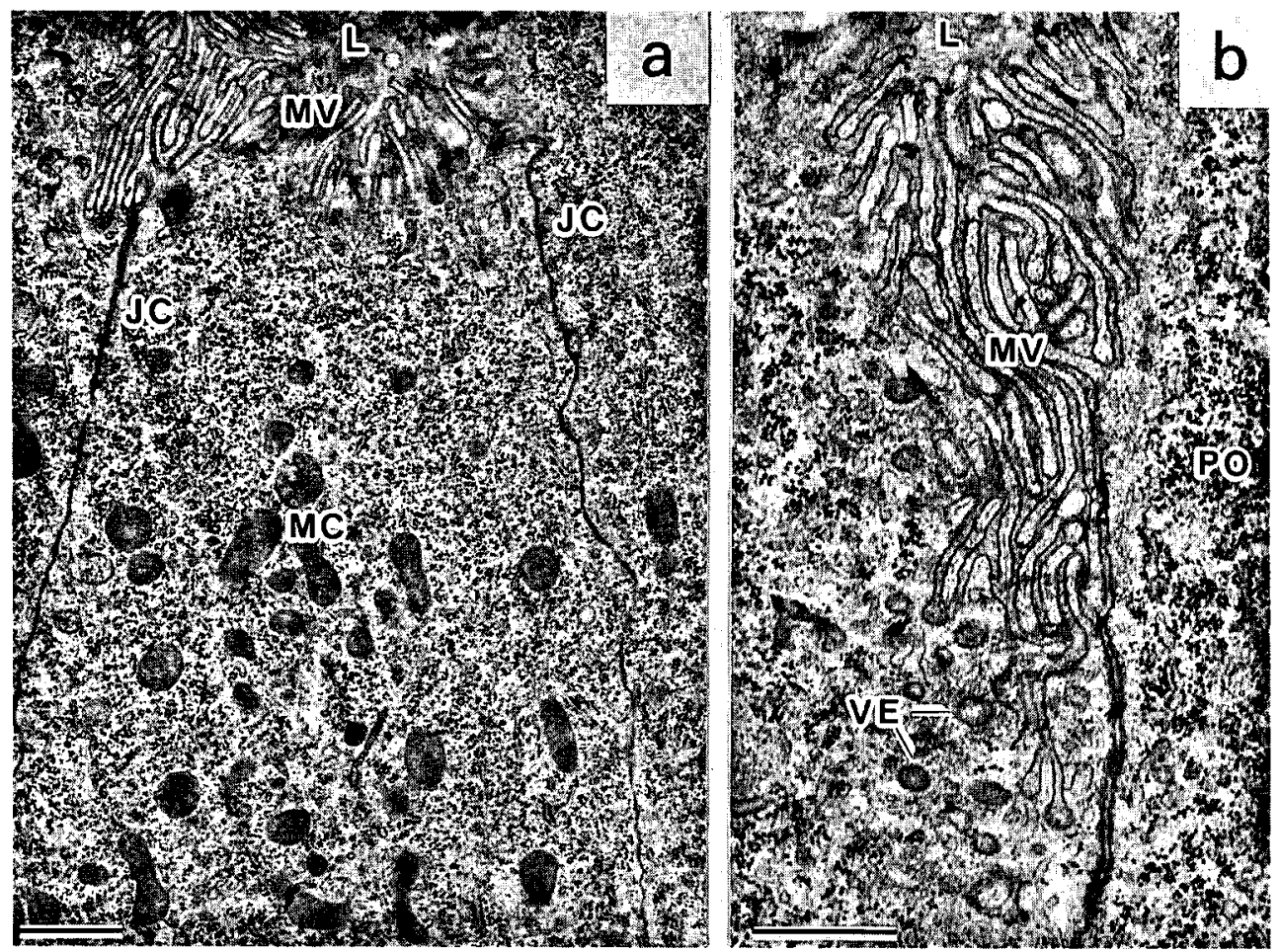

Fig. 9. Electron micrograph of the tubular gland of Gene's organ in the 10-day feeding virgin female. a: The apical region of the glandular epithelial cell. The junctional complex (JC) are located at the apical portion and the intercellular crypts are not present. b: Magnified view of the apical intercellular border. Small vesicles (VE) fuse with the plasma membrane. L: lumen, MC: mitochondrion, MV: microvilli, PO: polysome. (Bar $=1 \mu \mathrm{m})$

fatty acids and alcohol (Gilby, 1957; Cherry, $1969 \mathrm{a}$, b; McCamish et al., 1977), so the secretions from the tubular glands may be resynthesized into the egg wax after release into the lumen of the tubular glands.

\section{Acknowledgements}

We thank Professor R. Umezu and Dr. Y. Nakanishi (now Kagoshima University), Kuju Agricultural Research Center of Kyushu University, for facilities in collecting ticks on Kuju Highland.

摘 要

フタトゲチマダニにおけるジェネ器官管状腺の微細構造的変化に及ぼす吸血と交尾の影響 角田浩之・毛利孝之・白石 哲 (九州大学農学部動物学教室) 
産卵の際, 顎体窩から突出するジェネ器官は防水性のワックスを卵表に塗布する, 餒化に とって必要不可欠な器官である。雌フタトゲチマダニの発育に伴うジェネ器官管状腺の微細 構造は, 吸血と交尾の刺激に応じて劇的に変化する。まず，吸血の開始によって腺細胞は増 殖し, ついで頂端部形質膜への小胞の融合により膜成分の補給を行う。交尾と同時に, 細胞 間に微絨毛に富む深い細胞間陰窩が形成され，細胞表面積が著しく拡大される。この微絨毛 性の陰窩は交尾なしには形成されないことが未交尾実験によって確認された。陰窩の形成と 同時に, 細胞内には多量の貯蔵物質が蓄積される。産卵中のジェネ器官は多量のワックスを 分泌するにも拘らず，この時期の腺細胞は開口分泌を全く示さず，低分子物質が透過分泌に よって放出されることが示唆される。

\section{REFERENCES}

Arthur, D. R. (1953): The morphology of the British Prostriata with particular reference to Ixodes hexagonus Leach. II. Parasitology, 42: 161-186.

Balashov, Yu.S. (1972): Bloodsucking ticks (Ixodidae)-Vectors of diseases of man and animals. (transl., Strekalovski, O. G.) Misc. Publ. Entomol. Soc. Am., 8: 161-376.

Berridge, M. J. and J.L. Oschman (1972): Transporting Epithelia, 91 pp., Academic Press, New York.

Booth, T.F. (1989): Wax lipid secretion and ultrastructural development in the egg-waxing (Genés) organ in ixodid ticks. Tissue Cell, 21: 113-122.

Booth, T.F., D. J. Beadle and R. J. Hart (1984): The ultrastructure of Gené's organ in the cattle tick Boophilus microplus Canestrini. In: Acarology VI, Vol. 1. (eds., Griffiths, D. A. and C. E. Bowman), pp. 261-267, Ellis Horwood, Chichester.

Cherry, L.M. (1969a): The production of cuticle wax by engorged females of the cattle tick, Boophilus microplus (Canestrini). J. Exp. Biol., 50: 705-709.

Cherry, L. M. (1969 b): Cholesterol in the cuticular wax of Boophilus. Nature, 222: 777.

El Shoura, S. M. (1987): Fine structure of Gené's organ in the camel tick Hyalomma (Hyalomma) dromedarii (Ixodoidea: Ixodidae). J. Morphol., 193: 91-98.

Gilby, A. R. (1957): Studies of cuticular lipids of arthropods. III. The chemical composition of the wax from Boophilus microplus. Arch. Biochem. Biophys., 67: 320-324.

Kakuda, H., T. Mōri and S. Shiraishi (1992): Functional morphology of Genés organ in Haemaphysalis longicornis (Acari: Ixodidae). Exp. Appl. Acarol., 16: 263-275.

Lees, A. D. and J. W. L. Beament (1948): An egg waxing organ in ticks. Q. J. Microsc. Sci., 89: 291-332.

McCamish, M., G. R. Cannel and L. M. Cherry (1977): The nonpolar egg wax lipids of the cattle tick, Boophilus microplus (Canestrini). Lipids, 12: 182-187.

Palade, G. (1975): Intercellular aspects of the process of protein synthesis. Science, 189: 347-358. 